\title{
CHALLENGES AND POSSIBILITIES OF THE INTEGRATION OF ELECTRIC DRIVES IN MOBILE MACHINERY
}

\author{
Andreas Opgenoorth, Stefan Quabeck, Rik W. De Doncker, Katharina Schmitz \\ Institute for Fluid Power Drives and Systems, RWTH Aachen, Campus-Boulevard 30, 52072 Aachen; \\ * Corresponding author: Tel.: +49 24180 47724; E-mail address: Andreas.Opgenoorth@ifas.rwth-aachen.de
}

\section{ABSTRACT}

This paper provides an overview of the challenges and possibilities of the integration of electric drives into diesel-hydraulic excavators. Due to the drivers of emission reduction, the use of renewable energies and more energy efficient systems, a global push leads to the integration of electric drives in excavators. In mobile machinery such as excavators, new possibilities and challenges of the adaptation of the drive train and energy storage arise.

Rotational actuators can be powered by direct electric drives to avoid losses of the hydraulic system. Adapted hydraulic system topologies enable recuperation and reduce throttling losses in hydraulic systems. Variable and overall higher electric motor speeds reduce the size of the electric and hydraulic components and enable operation in more efficient operating points.

To evaluate possible changes to the traditional hydraulic excavator systems, a simulation model is built and the proposed adaptations are implemented. The paper concludes with the evaluation of the proposed system changes and an outlook for further possibilities of hydraulic system adaptions in relation to the electric drive.

Keywords: Excavator, Electric, Mobile Machinery, Battery, Energy, Emissions

\section{INTRODUCTION}

\subsection{Motivation}

In order to counteract climate change and improve air quality, it is necessary to reduce relevant sources of greenhouse gases and air pollution. Considerable $\mathrm{CO}_{2}$ emissions are caused by the construction industry. In the construction industry fossil fuels alone produce 300 million tons of $\mathrm{CO}_{2}$ per year, representing $1 \%$ of global $\mathrm{CO}_{2}$ emissions [1]. Furthermore, research by Helms show in 2014, the emission rate of $\mathrm{NO}_{\mathrm{x}}$ from mobile machinery was $20 \%$ of the emissions from the transport sector and the particulate pollution from mobile machinery was on a par with the transport sector [2]. The environmental and health burdens caused by $\mathrm{NO}_{\mathrm{x}}$ and particulate matter can only be reduced by complex exhaust gas after treatments. In particular, the avoidance of $\mathrm{CO}_{2}$ emissions directly in combustion engines is not possible [3].

Restrictions are being imposed politically worldwide to reduce emissions. In the transport sector, for example, Norway will forbid the registration of new cars driven by combustion engines from 2025, the Netherlands and Germany from 2030 and France from 2040 [4]. Whilst currently effective bans are limited to passenger cars, there are already efforts to extend these developments to all machines with combustion engines, such as Japan's plans to integrate the use of hydrogen in all energy sectors from 2030 to 2050 [5].

In order to reduce emissions for mobile machinery, clean energy sources have to be used. Compared to the emissions of the Diesel engine, electric energy, especially from renewable sources, can lower the $\mathrm{CO}_{2}$ emissions, as the $\mathrm{CO}_{2}$ equivalents of the Diesel engine and electric energy sources imply and is in the diagram including the electric grid and charging losses in Figure 1. 


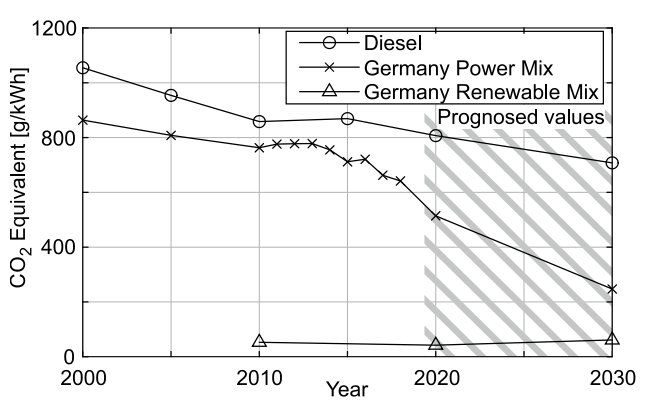

Figure 1: $\mathrm{CO}_{2}$ Emissions of power sources based on mechanic output [6-8]

As it already has emerged in the transportation sector, electric drives can achieve this task by using electric energy from renewable energy sources. Therefore, the challenge arises to integrate electric drives into mobile machinery, for which the example of an excavator is used as a baseline in this paper.

\subsection{Challenges}

It has already proven possible and feasible to integrate electric drives with lithium-ion batteries into mini excavators, as there are models with a weight up to $4 \mathrm{t}$ to be released from different manufacturers [9-11]. Nevertheless, for larger machines, challenges arise in the storage of the necessary electrical energy, as on the one hand the performance class of the machines increases and on the other hand the degree of utilization also rises. A 26-ton Caterpillar excavator prototype uses $300 \mathrm{kWh}$ of batteries, with a battery weight of 3.4 tons [12]. Considering the large amount of required batteries in relation to global demand, not only the cost of batteries but also their availability is challenging [13].

In addition to the challenges of storing the energy, the electric drive induces a changed system behavior and additionally enables new possibilities of variable engine speeds, direct electric drives and recuperation. Traditional hydraulic systems however are built for a single direction power flow using variable displacement pumps running at constant speeds [14]. By adapting the hydraulic system, the advantages of the electric drive system can be utilized to improve the excavator system in terms of energy efficiency, thus reducing the necessary stored energy [15].

\section{STATE OF THE ART}

The current development in the electrification of excavators is driven by requests of energyefficient and emission-free construction machinery [15]. Developments of battery technology and power electronics make it possible to build battery powered excavators, which can be operated for a working day without down time [9].

\subsection{Batteries and Power Electronics}

The first documented mobile application of electric was an electric car in 1827, even before the invention of the diesel engine in 1893 [16]. Nowadays, electric drives are used in a wide range of mobile applications, from small drives of only several watts for auxiliary drives to the 16.56 MW traction drive of a bucket-wheel excavator [17]. There are three types of electric machines which are used in most mobile drive applications: induction machines, synchronous machines and switched reluctance machines. The preferred machine type depends on the application. While switched reluctance machines are interesting for high-speed applications, synchronous machines achieve higher efficiency, and induction machines are cheaper and more reliable [18].

In most mobile drive applications, powerelectronic inverters are applied to control the machine speed and torque, especially when variable speed is required or the machines are fed from a dc source. These inverters consist of semiconductor switches, a control unit, and several filter elements. They can reach efficiencies of up to $98 \%$ [19].

The electric power for the drive can be supplied from a battery (dc source) or directly from the grid (ac source). For mobile machinery, batteries are preferable, as they allow full freedom of movement. They offer an efficiency of up to $97 \%$ from charging to discharging and energy densities of up to $240 \mathrm{Wh} / \mathrm{kg}$ [20]. For high-power applications and nearly uninterrupted operation, a direct connection to the grid is still the only feasible option.

\subsection{Electric Excavators}

There are three types of commercially available excavators using electric drives: Mining excavators, mini excavators and hybrid 
excavators. The history of electric mining excavators reaches back over 100 years with electric rope excavators [21]. Today electric excavators are still widely used in surface mining, especially in large machines. Main reasons for electric mining excavators are reduced fuel costs, reduced emissions and a higher up-time [22]. Electric mining excavators are generally powered by cable as the large amounts of energy cannot be stored in batteries and, as the excavators move very little, the use of a cable is possible. An example for a cable-based mining excavator is the Liebherr R 9200 E [23]. The 850-kW engine power of the $210 \mathrm{t}$ machine is made possible by a $6 \mathrm{kV}$ cable. A limit for larger scales does not exist, as the largest machine in the world is an electric mining excavator, the Bagger 288. The machine weighs $12.840 \mathrm{t}$ and the electric drives provide a sum of $16.56 \mathrm{MW}$ of power with a voltage supply of $30 \mathrm{kV}$ [17].

In contrary to mining excavators, mini excavators face different working environments and requirements. The installed engine power of available machines range from $7.5 \mathrm{~kW}$ in the Bobcat e10 excavator to $75 \mathrm{~kW}$ in the Suncar TB260E $[10,24]$. In addition, the utilization of the machines is lower compared to large excavators. This results in an overall low energy consumption and it can be feasible to use batteries as an energy source. In the available electric mini excavators, no adaptations of the hydraulic systems besides the integrated electric drives are published by the manufacturers.

Hybrid excavators use electric drives to improve energy efficiency and reduce the fuel consumption of their combustion engines. Hybrid crawler excavators by Komatsu and Hitachi rely on electric swings to recuperate the kinematic energy from the heavy machines. The manufacturers state fuel savings from $20 \%$ up to $40 \%[25,26]$.

\subsection{Excavator drive train}

The drive train of the excavator can be split up into the energy source, energy conversion and energy output. Traditionally, a diesel engine supplies the energy to the hydraulic system, which then directs it to the cylinders or engines. Topologies of the drive train of excavators are traditionally based on valve-controlled closedcenter or open-center systems. The key drives of an excavator include the cylinders of the working equipment, the swing to turn the upper carriage and the travel drive to move the excavator, as it is displayed in a simple form in Figure 2 [14, 27].

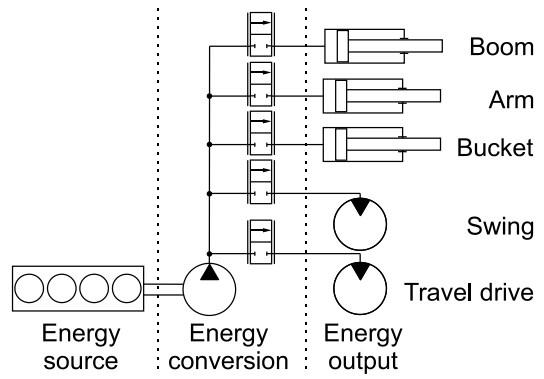

Figure 2: Traditional excavator system

\section{POSSIBILITIES FOR ELECTRIC DRIVE INTEGRATION}

In mobile applications, the diesel engine mostly runs at a fixed speed and it is physically impossible for the engine to recuperate energy. Based on those properties, the hydraulic systems are designed. The pumps run at a fixed speed and a possibility to recuperate negative loads is not included in the Load-Sensing or Open-Center systems [28]. With changing the energy transmitter to an electric machine, adaptations to the drive train are necessary to fully use the benefits of the electric drive.

\subsection{Direct Electric Drives}

In a hydraulic system, efficiency losses of the components cannot be avoided. Additionally, systematic losses due to throttling increase the required power of the system [29]. When using direct electric drives, the overall efficiency of the system can be improved. Rotational drives are directly powered by electric motors, while linear drives are powered by linear actuators or rotational motors with spindle drives. A major restriction for electric linear drives is the power density. Power densities of the hydraulic linear actuators are of magnitude 10 to 1000 higher compared to spindle drives with electric motors [30].

In contrast to electric linear drives, the power density of rotational high-speed drives is in the same order of magnitude as that of hydraulic drives. In 2009, Jacobs presents a comparison of the power densities of an electric high-speed drive with gearbox to an inclined axis and swashplate units with gearbox [31].The presented 
power density of the electric unit is $0.11 \mathrm{~kW} / \mathrm{kg}$ and that of the hydraulic units is $0.16 \mathrm{~kW} / \mathrm{kg}$. The application under consideration is a Baitrack BP 130/85 B mobile crusher. The benefit of a direct electric drive is the improved efficiency, especially in partial loads where the efficiency of the hydraulic units is sub-par [31].

In an excavator, the travel drive and the swing rotational movements can be powered by direct electric drives. To demonstrate a comparison of efficiency of the excavator, in chapter 4 the integration of an electric swing into the machine is evaluated based on a $90^{\circ}$ digging cycle.

\subsection{Dynamic Motor Speeds}

The use of power electronic inverters enables variable motor speeds. When combing a variable speed electric drive with a constant displacement pump, the hydraulic volume flow can be controlled by the motor speed and the losses of the pump controllercan be avoided. Another possibility is to use variable drive speeds in combination with a variable displacement pump. This gives the option of a dynamic operating point to improve the efficiency of the components.

As the power density of the electric drive improves with increasing speed, high speed drives are an interesting option for mobile applications [32]. For traction drives, a gearbox is required to achieve a reasonable rotational speed of the wheels. But especially for the working hydraulics, high speed machines combined with high speed constant displacement pumps can offer a large increase in power density. In combined research by the Institute for Machine Elements and Systems Engineering and Institute for Fluid Power Drives and Systems of the RWTH Aachen, it is demonstrated that an increased speed by an electric drive can reduce the necessary installation space considerably. An increase of the maximum rotational speed from $2200 \mathrm{1} / \mathrm{min}$ to $3800 \mathrm{1} / \mathrm{min}$ reduces the required installation space by $68 \%$, at $100001 / \mathrm{min}$ the installation space is reduced by $89 \%$ [33]. Using mechanic transmissions, high engine speeds can be integrated with moderate pump speeds.

\subsection{Recuperation}

As electric drives inherently allow bidirectional transformation of electrical and mechanical energy, they can be used to recuperate the breaking energy of the swing and the saved potential energy of the working hydraulics. Depending on the operating point, an efficiency of up to $95 \%$ of the electric drive can be reached. Electric recuperation systems are traditionally used in swings of hybrid excavators, such as products from Hitachi and Komatsu [25, 26]. In an excavator with an electric swing, the recuperation system can be integrated without further adaptions. The recuperation of negative loads of the linear drives proves more challenging, as the movement must be transferred into a rotational movement for the electric drive.

\section{DEMONSTRATION ON A COMPACT EXCAVATOR}

In order to evaluate the proposed adaptions for the electric excavator, the integration into the machine is demonstrated with a simulation model. In this simulation model, the kinematic and hydraulic system of a $9 \mathrm{t}$ compact excavator is modelled and used as a basis. In a $90^{\circ}$ dig and dump cycle, the adapted system behavior of the machine is evaluated.

\subsection{Modelling}

The simulation model consists of three parts, power source, hydraulic system and kinematic structure. The kinematic structure represents the movement of the excavator and determines the cylinder and swing load. The engine, in this model a diesel engine is compared to an induction motor, provides the power for the system. The most common hydraulic system for compact excavators is an Open-Center system [14]. The Open-Center system distributes the power to the hydraulic drives and defines the system behavior. For the excavator model, a public layout by Hitachi is used as a basis [34]. The simulation is built in AMEsim as a 0D simulation model.

The modelled compact excavator uses a $40.5 \mathrm{~kW}$ diesel engine. The specific fuel consumption of the diesel engine is optimal in a small area of the engine map, as it is displayed in Figure 3. 


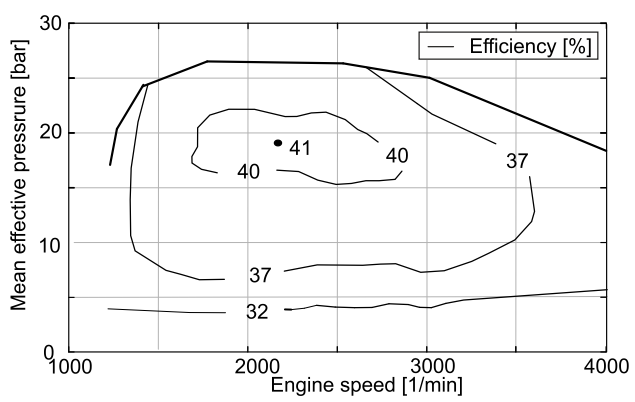

Figure 3: Diesel fuel consumption [35]

In contrast to the restricted work point of the diesel engine, the induction motor can be varied in a larger area without a major efficiency drop. In Figure 5 the efficiency map of an asynchronous machine with inverter is displayed.

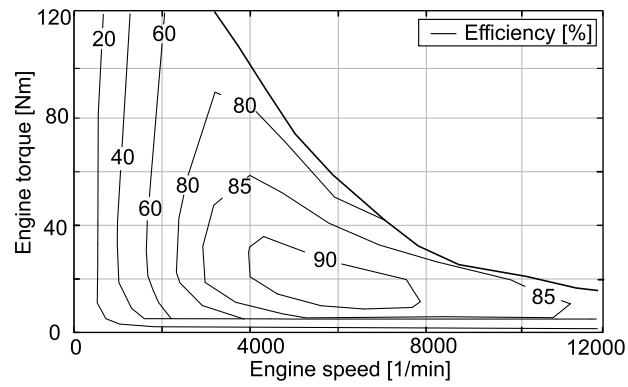

Figure 5: Efficiency induction motor with
Two variable displacement axial pump-motorunits size 36 are used in Open-Center system of the simulation model. The pump adjustment and valve actuation are modelled with a hydraulic pilot system but also with a direct electric actuation. A pilot system with a pilot pump volume flow of $20 \mathrm{~L} / \mathrm{min}$ and a pilot pressure of $36 \mathrm{bar}$ is used. To model the hydraulic losses of the pump controller, a bypass orifice is set according to measurements from Lux [37]. At a pump pressure of 200 bar, a volume flow of $2.8 \mathrm{~L} / \mathrm{min}$ is used for the controller. The energy consumption of $28 \mathrm{~W}$ of the Parker RE06M*W is used for the electric pump controllers without a pilot pressure system [38]. For the electric swing break, the ROBAstop-M of the manufacturer Mayr is assumed [39]. For direct actuated valves, the energy consumption of the Parker D3FB, a proportional NG10 4/3 way valve is considered as data for the energy consumption of a direct controlled open-center valve of this size is not available [40].

In case of the electric engine, the engine speed can be set dynamically to run the pumps and the electric drives at more efficient operating points. In addition, the possibility of fixed displacement units with variable engine speeds arise. This method of flow control avoids using a pump controller and reduces by-pass losses [37]. inverter [36]
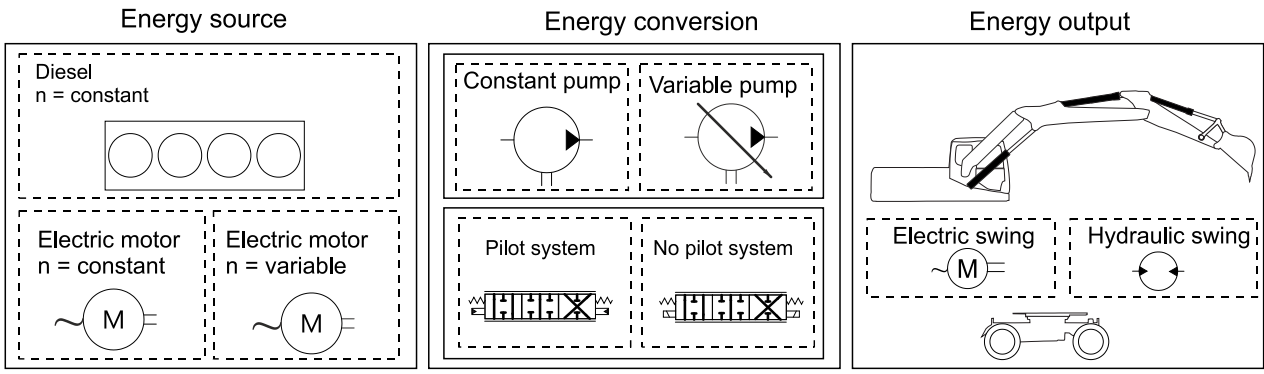

Figure 4: $\quad$ Excavator system layout and variants

An overview of the possible adaptions and the model layout presents Figure $\mathbf{4}$ and as a list the explicit tested variants Table 1. 
Table 1: Model combinations

\begin{tabular}{llllll}
\hline \# & Motor & $\begin{array}{l}\text { Motor } \\
\text { speed }\end{array}$ & Swing & Pump & $\begin{array}{l}\text { Pilot } \\
\text { system }\end{array}$ \\
\hline 1 & Diesel & Constant & Hydr. & Variable & Yes \\
2 & Electric & Constant & Hydr. & Variable & Yes \\
3 & Electric & Constant & Electr. & Variable & Yes \\
4 & Electric & Variable & Electr. & Constant & Yes \\
5 & Electric & Variable & Electr. & Variable & Yes \\
6 & Electric & Variable & Electr. & Constant & No \\
\hline
\end{tabular}

\subsection{Test Cycle}

In order to determine the forces impressed on the bucket, a model is used in which the digging forces are determined based on the current grave cross section, the grave movement and material parameters [41].

The movement of the test cycle is according to a $90^{\circ}$ dig and dump cycle. The excavating movement of the excavator bucket is displayed in Figure 6.

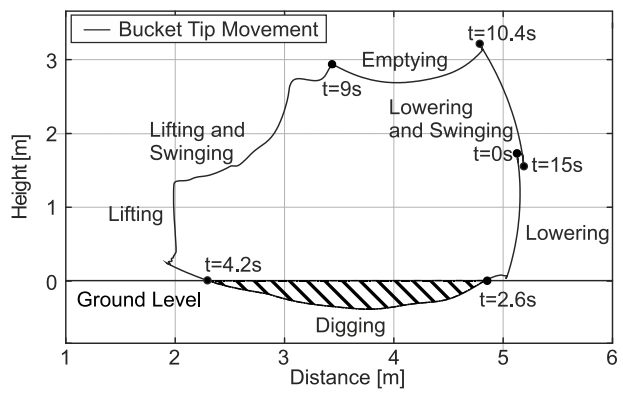

Figure 6: Excavating movement

The cycle starts with the empty bucket in the air. At first the boom is lowered, then in movement of all three cylinders the surface is dug out. It is followed by a lifting of the boom whilst turning the bucket to keep the dug ground material in it. With an upwards movement of the bucket by a movement of the boom and arm, the machine swings to the side. In a height of $2.8 \mathrm{~m}$, the bucket is emptied and the excavator moves back to the initial position.

\subsection{Evaluation}

In the evaluation, the required power, operational costs and the impact on the carbon footprint are compared. Systematic losses appear in the hydraulic system due to throttling losses. Efficiencies of the pumps, the Diesel or electric engine further increase the required power. Considering a battery powered excavator, additional losses of charging and discharging the battery are considered. Research of Huss determined expected efficiencies of electric batteries in the year 2020 of $\eta_{\text {Battery }}=80.9 \%$ [7]. An additional power loss is induced by losses in the power grid, which are elaborated by Mehlhorn with an average grid efficiency in Germany of $\eta_{\text {Grid }}=95.3 \%$ [8]. This concludes in a required power for the electric machine $P_{\text {Grid }}$ as shown in Equation 1.

$P_{\text {Grid }}=\frac{P_{\text {Load }}}{\eta_{\text {Grid }} \cdot \eta_{\text {Battery }} \cdot \eta_{\text {Drive }} \cdot \eta_{\text {Pumps }} \cdot \eta_{\text {Hydraulic }}}$

For the Diesel engine, the required chemical power is determined as in Equation 2.

$P_{\text {Diesel }}=\frac{P_{\text {Load }}}{\eta_{\text {Diesel }} \cdot \eta_{\text {Pumps }} \cdot \eta_{\text {Hydraulic }}}$

The energy consumption is defined as the use of diesel or electric power. The operational expenditure (OPEX) is the calculated cost based on the energy consumptions. Based on the lower calorific value of Diesel $H_{\mathrm{u}}$ with $43 \mathrm{MJ} / \mathrm{kg}$ and the density $\rho_{\text {Diesel }}$ with $0.84 \mathrm{~kg} / \mathrm{L}$, the required Diesel consumption $\dot{V}_{\text {Diesel }}$ is determined as in Equation 3 [28].

$\dot{V}_{\text {Diesel }}=\frac{P_{\text {Diesel }}}{H_{\mathrm{u}} \cdot \rho_{\text {Diesel }}}$

With the relative costs of the Diesel $C_{\text {Diesel }}$, the OPEX are determined. As a basis, the Diesel costs of 2018 in Germany is used. The average price without value added taxes is $1,009 € / \mathrm{L}$ and with value added taxes $1,289 € / \mathrm{L}$. The OPEX is determined as in Equation 4 [42, 43].

$O P E X_{\text {Diesel }}=\dot{V}_{\text {Diesel }} \cdot C_{\text {Diesel }}$

For the electric excavator, the OPEX is based on the electricity costs for industry users with and without taxes. Without taxes, the price $C_{\text {Electricity }}$ in 2018 is at $8.97 €$ cent $/ \mathrm{kWh}$ and with taxes $18.44 € c e n t / k W h$ [44]. The determination of the OPEX excludes the grid losses, as the price calculations of the consumers is based on the delivered energy.

$O P E X_{\text {Electric }}=P_{\text {Grid }} \cdot \eta_{\text {Grid }} \cdot C_{\text {Electricity }}$

The $\mathrm{CO}_{2}$ emissions of the electric excavator $E_{\text {Electricity }}$ are determined based on the $\mathrm{CO}_{2}$ equivalent of the German power mix and also based on the German electro mobile renewable mix. For the general German power mix, the 
specific $\mathrm{CO}_{2}$ equivalent $e_{\text {Electricity }}$ for 2019 is $445.7 \mathrm{gCO}_{2} / \mathrm{kWh}$ and for the renewable mix for electro mobile applications, the $\mathrm{CO}_{2}$ equivalent is $43.3 \mathrm{gCO}_{2} / \mathrm{kWh}$ [6]. Included in the consideration of the $\mathrm{CO}_{2}$ equivalent is the production and recycling of the lithium ion batteries. For this, a battery with a lifetime of $2000 \mathrm{~h}$, a size to be able to run 4 hours under maximum load and a $\mathrm{CO}_{2}$ equivalent of $175 \mathrm{kgCO}_{2} / \mathrm{kWh}$ is considered [45].

$E_{\text {Electricity }}=P_{\text {Grid }} \cdot e_{\text {Electricity }}+E_{\text {Battery }}$

The $\mathrm{CO}_{2}$ equivalent of the Diesel engine $E_{\text {Diesel }}$ is specified by a [6] $\mathrm{CO}_{2}$ equivalent $e_{\text {Diesel }}$ of $819.5 \mathrm{kgCO}_{2} / \mathrm{kWh}$. The value is based on the mechanic power output of an average Diesel engine in Germany in 2019 [6].

$E_{\text {Diesel }}=P_{\text {Diesel }} \cdot \eta_{\text {Diesel }} \cdot e_{\text {Diesel }}$

The required power and the losses in the drive train is displayed in Figure 7. The average power consumption is displayed at the top, the efficiency losses of the drive train relative to its required power next to the bars. The variants are detailed in Table 1.

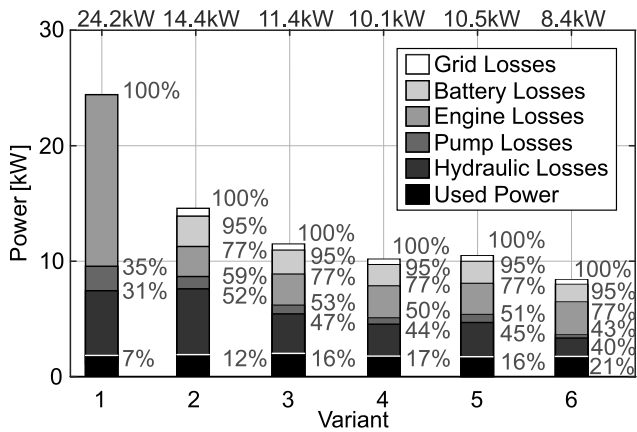

Figure 7: Power variants

Starting with the sole replacement of the diesel engine, first variant, by an electric motor, second variant, a significant change in the system behavior and efficiency cannot be noted. A $32 \mathrm{~kW}$ electric drive is able to power the system. In the third variant, in addition to the electric traction drive, the swing is electrically powered by an $8 \mathrm{~kW}$ electric drive. The electric drive allows negative energies to be recovered with corresponding efficiencies and additionally reduces throttle losses in the system. With the electric rotary actuator, a significant improvement of the drive system is possible, as the consumption of the electrical input power is reduced by $21 \%$ compared to the second variant.

In variants four and five, in addition to the electric swing, variable motor speeds are considered, on the one hand with a constant pump and on the other hand with a variable displacement pump. In both variants the power consumption of the machine is reduced even further. In case of the variant with constant pumps, the average efficiencies of the constant pumps are higher compared to the dynamic use of the variable displacement pumps and the hydraulic pump controller losses are avoided. In case of the variable displacement pumps at variable speeds, the relation of the pump rotation speeds and swivel angles is set for the most optimal work point based on the pressure and volume flow. Overall, the variable speed variants are able to reduce the power consumption further by $8-11 \%$ for a total $30 \%$ in variant four.

In the last adaption, an electric actuation system is considered and variant four is adapted with the electric actuation system. As the pilot system is not used, the power intake of the machine is lowered by another $17 \%$ and the total efficiency is improvement by $42 \%$. The avoidance of the pilot system is displayed in more detail in Figure 8, as the power consumption of the electric actuation is compared to the required electric power to drive the pilot pump.

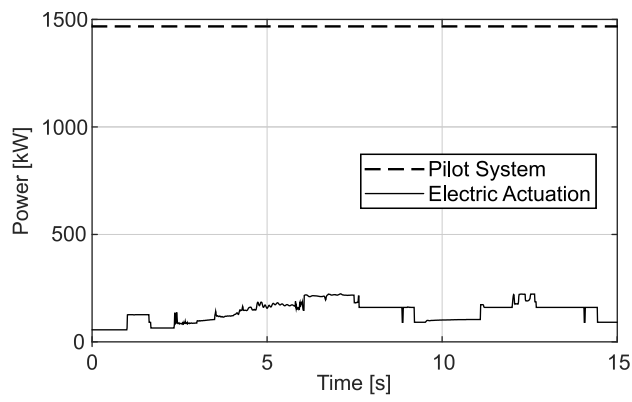

Figure 8: Electric valve actuation power consumption

With the required average power intake of the electric actuation of $138 \mathrm{~W}, 1329 \mathrm{~W}$ of electric power can be saved.

According to the power intake of the machine, the operational expenditure (OPEX) displayed in Figure 9. 


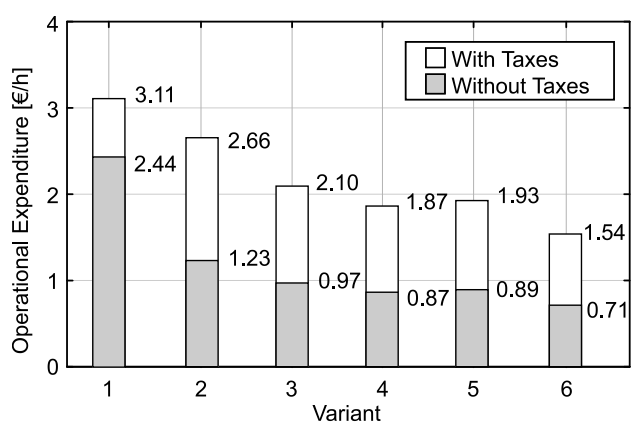

Figure 9: Operational expenditure

Even in the variant two without an electric swing, the operational costs are reduced by $15 \%$ while in the system with the lowest power intake, the costs to operate the machine are reduced by $50 \%$ compared to the Diesel engine. Further reductions are possible with tax breaks, which currently exist for electric cars.

The $\mathrm{CO}_{2}$ equivalents of the different variants are displayed in Figure 10. The $\mathrm{CO}_{2}$ production is elaborated for the Diesel engine, the use of the overall German power mix or the use of the renewable energy mix (RE) and under the use of a battery powered excavator or without the battery.

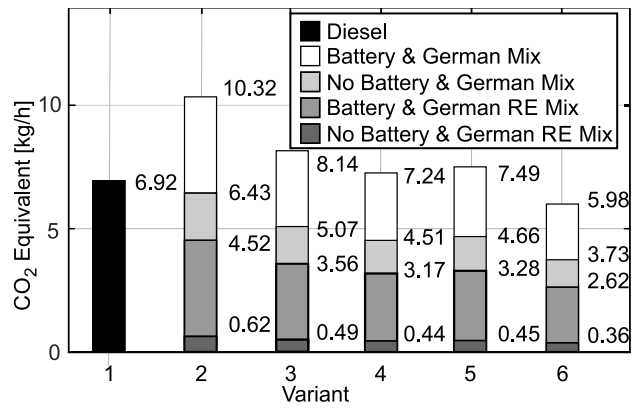

Figure 10: $\mathrm{CO} 2$ emissions

As it can be seen, the possible $\mathrm{CO} 2$ emissions of the excavator heavily depend of the system variant. Under the use of the German power mix and a battery, a $\mathrm{CO}_{2}$ reduction is not possible. But under consideration of the use of renewable energy sources, even with a battery the $\mathrm{CO}_{2}$ equivalent can be reduced by $68 \%$ in variant six. The largest contributor remains the battery production, as without the consideration of the battery, the $\mathrm{CO}_{2}$ emissions are reduced from $6.92 \mathrm{~kg} / \mathrm{h}$ of the Diesel engine to a $0.36 \mathrm{~kg} / \mathrm{h}$ with renewable energy sources.

\section{CONCLUSION AND OUTLOOK}

Electrically powered excavators present a possibility to reduce $\mathrm{CO}_{2}$ emissions and operational costs. In this paper system adaptations are elaborated and compared.

A major contribution to efficiency improvements are electric swings. Using a direct electric drive of the excavator rotation, hydraulic losses are reduced and parts of the kinetic energy can be recovered while breaking. In the simulated compact excavator, efficiency improvements of over $21 \%$ are possible.

Under the use of electric drives, variable motor speeds are able to further improve the system efficiencies. The use of constant displacement pumps with variable speeds improves the efficiencies of the components and avoids pump controller losses. Variable displacement pumps can be powered in more efficient operating points with variable motor speeds. With variable motor speeds, the efficiency of the system with electric swings is further improved by $8-11 \%$.

Electric valve, pump and break control can be used to remove the losses of the pilot system. In the case of the electric excavator, the system losses are reduced by $17 \%$.

With the proposed adaptations of the hydraulic system, a total efficiency improvement of $42 \%$ of the electric excavator is possible.

Further improvements can be focused on the adaptions of the layout of the hydraulic excavator, as the hydraulic losses are $74 \%$ of the total losses under the use of the hydraulic swing and $48 \%$ under the use of the electric swing.

\section{NOMENCLATURE}

Electr. Electric

Hydr. Hydraulic

OPEX Operational Expenditure

$R E \quad$ Renewable Energy

\section{REFERENCES}

[1] Huanga L, Krigsvolla G, Johansena F et al. (2017) Carbon emission of global construction sector. Renewable and Sustainable Energy Reviews

[2] Helms H, Heidt C (2014) Erarbeitung eines Konzepts zur Minderung der Umweltbelastung aus NRMM (non road mobile machinery) unter Berücksichtigung aktueller Emissionsfaktoren 
und Emissionsverminderungsoptionen für den Bestand

[3] Umweltbundsamt (2009) Feinstaubbelastung in Deutschland.

https://www.umweltbundesamt.de/sites/default/ files/medien/publikation/long/3565.pdf.

Accessed 22 Jul 2019

[4] Burch I, Gilchirst J (2018) Survey of Global Activity to Phase Out Internal Combustion Engine Vehicles.

https://climateprotection.org/wpcontent/uploads/2018/10/Survey-on-GlobalActivities-to-Phase-Out-ICE-Vehicles-FINALOct-3-2018.pdf. Accessed 23 Jul 2019

[5] Ministerial Council on Renewable Energy, Hydrogen and Related Issues (2017) Basic Hydrogen Strategy.

https://www.meti.go.jp/english/press/2017/1226 003.html. Accessed 23 Jul 2019

[6] International Institute for Sustainability Analysis and Strategy (2019) Gemis 5.0

[7] Huss A, Maas H, Hass H (2013) Well-towheels analysis of future automotive fuels and powertrains in the European context. Tank-towheels report, version 4.0

[8] Mehlhorn K, Kliemt J (2004) Moderne Netzanalyse

[9] Wacker Neuson (2019) Emissionsfrei, leise und leistungsstark - Die elektro Minibagger EZ17e und EZ26e.

https://www.wackerneuson.de/de/aktuelles/new s/ez17e/. Accessed 23 Jul 2019

[10] Bobcat (2019) E10electric. https://www.bobcat.com/eu/de/companyinfo/news-media/e10-electric. Accessed 15 Oct 2019

[11] JCB (2019) Electric Mini Excavator 19C-IE. https:/www.jcb.com/en-us/products/compactexcavators/19c-1e. Accessed 16 Oct 2019

[12] Lambert F (2019) Caterpillar unveils an allelectric 26-ton excavator with a giant $300 \mathrm{kWh}$ battery pack. https:/electrek.co/2019/01/29/caterpillarelectric-excavator-giant-battery-pack/. Accessed 15 Oct 2019

[13] Vikström H, Davidsson S, Höök M (2013) Lithium availability and future production outlooks. Applied Energy 110

[14] Murrenhoff H., Eckstein L (2011) Fluidtechnik für mobile Anwendungen

[15] Lajunen A, Sainio P, Laurila L et al. (2018) Overview of Powertrain Electrification and
Future Scenarios for Non-Road Mobile

Machinery. energies 11(5)

[16] Guarnieri M (2012) Looking back to electric cars. In: Staff I (ed) 2012 Third IEEE History of Electro-Technology Conference

[17] thyssenkrupp AG (2019) Bagger 288 - Ein Gigant unter den Schaufelradbaggern. https://www.thyssenkrupp-industrialsolutions.com/de/produkte-undservices/miningsystems/schaufelradbagger/bagger-288. Accessed 15 Oct 2019

[18] Finken T, Felden M, Hameyer K (2008) Comparison and design of different electrical machine types regarding their applicability in hybrid electrical vehicles. In: International Conference on Electrical Machines, 2008

[19] Maswood A, Vu P, Rahman M (2012) Silicon carbide based inverters for energy efficiency. In: IEEE Transportation Electrification Conference and Expo, Dearborn

[20] Becker J (2017) Flexible Dimensionierung und Optimierung hybrider LithiumIonenbatteriespeichersysteme mit verschiedenen Auslegungszielen. Dissertation, RWTH Aachen

[21] Komatsu History. Komatsu Germany GmbH. https://www.komatsumining.de/company/history/. Accessed $10 \mathrm{Sep}$ 2019

[22] Andreev R (2015) Evaluation of Hydraulic Excavator and Rope Shovel Major Maintenance Costs in Operation, University of Alberta

[23] Liebherr (2019) R 9200 E. https://www.liebherr.com/de/int/bauma/exponat e/mining/miningbagger/details/r9200e.html. Accessed 15 Oct 2019

[24] SUNCAR HK AG (2019) TB260E. Batteriebetriebener Elektrobagger. https://www.suncar-hk.com/files/datenblattTB260E.pdf. Accessed 15 Oct 2019

[25] Komatsu (2019) Wir sind Hybrid. https://www.komatsu.eu/de/komatsuhybridsystem. Accessed 15 Oct 2019

[26] Hitachi (2019) Die logische Wahl. https://www.hitachicm.eu/de/hybrid/. Accessed 15 Oct 2019

[27] Schmitz K, Murrenhoff H (2018) Grundlagen der Fluidtechnik

[28] Baehr H D, Kabelac S (2016) Thermodynamik. Springer-Verlag Berlin Heidelberg 
[29] Vukovic M, Leifeld R, Murrenhoff H (2017) Reducing Fuel Consumption in Hydraulic Excavators. energies

[30] Janocha H (2010) Unkonventionelle Aktoren. Oldenbourg Wissenschaftsverlag, München

[31] Schröter J, Jacobs G (2014) High speed electrical drives for mobile machinery - Drive concept and selected components. In: 13th CTI Symposium, Berlin

[32] Gerada D, Mebarki A, Brown N L. et al. (2014) High-Speed Electrical Machines: Technologies, Trends, and Developments. IEEE Trans. Ind. Electron. 61(6)

[33] Roth D, Jacobs G, Kramer A, Krech M, Pietrzyk T, Schmitz K (2019)

Bauraumreduktion durch Drehzahlanhebung Einsatz von High-Speed-Antrieben in elektrohydraulischen Linearaktuatoren für mobile Anwendungen. In: 7. Fachtagung Hybride und energieeffiziente Antriebe für mobile Arbeitsmaschinen, Karlsruhe

[34] Hanakawa K, Mutsuhashi M, Nakamura T (2011) Hydraulic circuit system for hydraulic excavator. Patent(US20110061755A1). https://patents.google.com/patent/US201100617 $55 \mathrm{~A} 1 / \mathrm{en}$

[35] van Basshuysen R, Schäfer F (eds) (2012) Handbuch Verbrennungsmotor. Grundlagen, Komponenten, Systeme, Perspektiven, 6th edn. ATZ-MTZ-Fachbuch. Vieweg + Teubner, Wiesbaden

[36] Göhlich D, Fay T A, Jefferies D et al. (2018) Design of urban electric bus systems. Design Science 4

[37] Hartmann K, Frerichs L (2016) Development of innovative solutions for displacement variation in hydrostatic machines. In: 10th International Fluid Power Conference (10. IFK), Dresden

[38] Parker Hannifin Corporation (2018) Axialkolbenpumpen - Serie PVplus Verstellbare Ausführung. https://www.parker.com/Literature/PMDE/Cata logs/Piston_Pumps/PV+/MSG30-3245_DE.pdf. Accessed 15 Oct 2019

[39] Mayr GmbH (2018) ROBA-stop-M. https://www.mayr.com/synchronisation/docume ntations/k_891_v17_de_26_03_2018.pdf. Accessed 16 Oct 2019

[40] Parker Hannifin Corporation Proportional Directional Control Valves Series D3FB. Catalog HY14-2550/US. https://www.parker.com/Literature/Hydraulic\% 20Valve\%20Division/hydraulicvalve/Catalog\% 20sections $\% 20$ for $\% 20$ websphere/Proportional \%20Directional\%20Control/Catalog\%20$\% 20$ Static\%20Files/D3FB.pdf. Accessed 16 Oct 2019

[41] Liu Y, Hasan M S, Yu H-N (2010) Modelling and remote control of an excavator. Int. J. Autom. Comput. 7(3)

[42] Mineralölwirtschaftsverband Deutschland e.V. (2019) Monatliche Verbraucherpreise für Mineralölprodukte 2005-2019.

https://www.mwv.de/statistiken/verbraucherprei se/. Accessed 16 Oct 2019

[43] Bundesverband Güterkraftverkehr Logistik und Entsorgung (BGL) e.V. (2019) DieselpreisInformation (Großverbraucher) - Vorabfassung für September 2019. https://www.bglev.de/images/downloads/dieselpreisinformation .pdf. Accessed 16 Oct 2019

[44] BDEW Bundesverband der Energie- und Wasserwirtschaft e.V. (2019) BDEWStrompreisanalyse Juli 2019. https://www.bdew.de/media/documents/190723 _BDEW-Strompreisanalyse_Juli-2019.pdf. Accessed 16 Oct 2019

[45] Romare M, Dahllöf L (2017) The Life Cycle Energy Consumption and Greenhouse Gas Emissions from Lithium-Ion Batteries. https://www.ivl.se/download/18.5922281715bd aebede9559/. Accessed 25 Oct 2019 